\title{
Effects of Duroc Breeding Lines on Carcass Composition and Meat Quality
}

\author{
Jung-Seok Choi ${ }^{1,2}$, Sang-Keun $\mathrm{Jin}^{2}$, Yang-II Choi ${ }^{1}$, and Jae-Joon Lee* \\ Department of Food and Nutrition, Chosun University, Gwangju 500-759, Korea \\ ${ }^{1}$ Department of Animal Science, Chungbuk National University, Cheongju 361-763, Korea \\ ${ }^{2}$ Department of Animal Resources Technology and Swine Science \& Technology Center, \\ Gyeongnam National University of Science and Technology, Jinju 660-758, Korea
}

\begin{abstract}
This study was performed to investigate the carcass composition and pork quality of Duroc breeding lines in Korea. A total of 200 Duroc pigs were used, and those were originated from four different great-grandparent (GGP) breeding stock farms (L1: N farm, L2: W farm, L3: S farm, L4: R farm). The carcasses of pigs from these farms were collected, and meat quality traits were evaluated. L1 and L2 had smaller carcass weights and thin backfat, whereas L3 and L4 had heavy carcass weights and thick backfat. L3 and L4 had higher contents of fat and protein than L1 and L2. For the meat quality characteristics, L1, L2, and L4 had higher $\mathrm{pH}$ values than L3. In addition, L4 had higher water holding capacity than the other lines. L4 had the highest sensory evaluation scores with regard to both juiciness and flavor. Consequently, the study results indicate that pork quality information from domestic Duroc breeding stock lines could be used to effectively improve pork quality in Korea.
\end{abstract}

Key words: Duroc, backfat thickness, $\mathrm{pH}$, water holding capacity, sensory evaluation

\section{Introduction}

Economic development and increase in national income resulted in increased meat intake of Koreans. In 2012, there was an average consumption of $19.2 \mathrm{~kg}$ of pork, 9.7 $\mathrm{kg}$ of beef, and $11.6 \mathrm{~kg}$ of chicken per capita. In addition, pork consumption has steadily increased each year in Korea (MAFRA, 2014). Korean consumers tend to prefer marbled meat to lean meat. Highly marbled meat shows high lipid content. Intramuscular fat provides many sensory properties such as flavor and aroma volatiles, increase in tenderness and juiciness, and supplement of essential fatty acids (Kang et al., 2010; Ngapo et al., 2012a, 2012b). It is clear that intramuscular fat has a significant impact on meat quality characteristics. Moreover, some factors that affect meat quality characteristics include sex, species, age, feed, and environmental conditions. These factors affect meat quality characteristics including water holding capacity (WHC), meat color, $\mathrm{pH}$, shear force, sensory characteristics, and storage character-

*Corresponding author: Jae-Joon Lee, Department of Food and Nutrition, Chosun University, Gwangju 500-759, Korea. Tel: +82-62-230-7725, Fax: +82-62-234-7452, E-mail: leejj80@ chosun.ac.kr istics (Betram et al., 2007; Channon et al., 2004; D'Souza and Mullan, 2002; Wang et al., 2014). Researchers at livestock research institutes and universities worldwide have conducted studies to improve meat quality characteristics and meat productivity (Knap et al., 2001; Kolstad et al., 1996; Tizioto et al., 2012).

In Korea, three-way crossbred pigs ([Landrace $\times$ Yorkshire] $\times$ Duroc) are mainly used for commercial purposes and have a large litter size, fast growth performance, and high meat yield (Kim et al., 2006; Kim et al., 2011; Park et al., 1981). In Korea, the Duroc breed is used as a terminal sire when fattening pigs are produced. Additionally, this breed has both an excellent growth rate and higher intramuscular fat (Suzuki et al., 2003). Duroc breeds imported from foreign countries are reared in domestic farms and the sperm is sent to commercial pig farms in Korea. However, meat quality and marbling forming ability in Duroc breeds were not compared using objective data, and exact meat quality information regarding breeding stock lines in Korea was not provided. Moreover, breeding stock businesses have been importing Duroc breeds from other countries. It is necessary to investigate the meat quality of Duroc lines and compare the meat qualities of lines in Korea. Therefore, the objective of this study is to investigate the pork quality of four 
Duroc breeding stock lines in Korea.

\section{Materials and Methods}

\section{Animals and sampling}

Pig breeding stock lines in this study were classified into four lines that are established domestic Duroc herds from respective great-grandparent (GGP) farms that were imported from foreign Duroc breeding stocks (Table 1). A total of 200 Duroc pigs were part of a pig improvement network program from November 2010 to December 2011 in the Korea Animal Improvement Association. At each of the farms, pigs were raised according to the Korean feeding standard for swine of the National Institute of Animal Science (2007). When the mean weight of pigs in a pen reached market weight, pigs were conventionally slaughtered and then chilled overnight. At $24 \mathrm{~h}$ postmortem, carcass traits including backfat thickness and carcass weight evaluated by the animal products grading service of Korea Institute for Animal Products Quality Evaluation (2001). The longissimus muscle from left side between the 5th and 13th rib was removed, and backfat was removed from the longissimus muscle. Then, meat qualities were evaluated at the Meat Science Laboratory of Chungbuk National University.

\section{Carcass characteristics}

The carcass weight and backfat thickness were measured based on the cold carcass grading system in the Korea Institute for Animal Products Quality Evaluation. The carcass length was measured from the 6th cervical vertebral to the H-bone on the left side.

\section{pH}

Using a homogenizer (Nihonseiki, Japan), $10 \mathrm{~g}$ of samples was homogenized in $100 \mathrm{~mL}$ of distilled water for 30 $\mathrm{s}$ at $7000 \mathrm{rpm}$. The $\mathrm{pH}$ levels of the homogenate were determined using a pH meter (Mettler Delta 340, MettlerToledo, Ltd., UK).

\section{Meat color}

The $\mathrm{L}^{*}, \mathrm{a}^{*}$, and $\mathrm{b}^{*}$ values refer to the Hunter lab color system ( $\mathrm{L}^{*}=$ lightness, $\mathrm{a}^{*}=$ redness, $\mathrm{b}^{*}=$ yellowness) using a white fluorescent light (D65) as light source and were determined on the surface of freshly cut meat after a 20 min bloom time using a Spectro Colormeter (Model JX777, Color Techno. System Co., Japan) calibrated to the white plate $\left(L^{*}, 89.39 ; a^{*}, 0.13 ; b^{*},-0.51\right)$. Each measurement was performed in six replicates, and the mean value was used as the assay result.

\section{WHC}

The centrifugation method described by Laakkonen et al. (1970) was used to measure WHC. Longissimus muscle samples $(0.5 \pm 0.05 \mathrm{~g})$ from each line were placed in a centrifugation tube with filter units, heated for $20 \mathrm{~min}$ at $80^{\circ} \mathrm{C}$, and then cooled for $10 \mathrm{~min}$. Samples were centrifuged at 2,000 $\mathrm{g}$ for $10 \mathrm{~min}$ at $4^{\circ} \mathrm{C}$, and $\mathrm{WHC}$ was calculated as the change of sample weight.

\section{Drip loss}

A 2-cm-thick slice (weight, $100 \pm 5 \mathrm{~g}$ ) cut from longissimus muscle was placed into a polypropylene bag and then vacuum packaged and stored for $24 \mathrm{~h}$ at $4^{\circ} \mathrm{C}$. Drip loss was calculated as the weight difference of the samples.

\section{Proximal analysis}

The moisture, protein, fat, and ash contents were assayed according to the AOAC methods (1995).

\section{Cooking loss}

A $3 \mathrm{~cm}$-thick slice (weight, $100 \pm 5 \mathrm{~g}$ ) that was cut from the longissimus muscle was placed into a polypropylene bag, cooked for $40 \mathrm{~min}$ at $70^{\circ} \mathrm{C}$ in a water bath, and cooled to room temperature. Cooking loss was calculated by the weight difference of the samples.

\section{Shear force}

A $3 \mathrm{~cm}$ thick slice (weight, $100 \pm 5 \mathrm{~g}$ ) cut from longissimus muscle was placed into polypropylene bag and then cooked for $40 \mathrm{~min}$ at $70^{\circ} \mathrm{C}$ in the water-bath and then cooled for $30 \mathrm{~min}$. Samples were cut into $1 \times 2 \times 1 \mathrm{~cm}$ (width $\times$ length $\times$ height) pieces, and max weight was determined by a shearing, cutting test using a Rheo meter (Model Compac-100, Sun Scientific Co., Japan) under the following operational conditions: Table Speed of 110 $\mathrm{mm} / \mathrm{min}$, Graph Interval of $20 \mathrm{~ms}$ and Load Cell (max) of

Table 1. Classification of Duroc breeding stock lines in Korea

\begin{tabular}{ccccc}
\hline \hline Terms & Line 1 & Line 2 & Line 3 & Line 4 \\
\hline \multirow{2}{*}{ Great grandparents stock farms } & N farm & W farm & S farm & R farm \\
& (Sweden, Ireland) & (France) & (France) & (USA, Canada) \\
\hline
\end{tabular}


$10 \mathrm{~kg}$ using Rheology Data System (RDS) Ver. 2.01.

\section{Sensory evaluation}

Well-trained in-house tasting panelists $(n=5)$ evaluated sensory attributes of tenderness, juiciness, flavor, and overall acceptability using on a 5-point scale with 1 representing samples that were very tough, dry, mild, and unacceptable and 5 representing samples that were very tender, juicy, intense, and acceptable. The sample was independently evaluated by the panelists three different times.

\section{Statistical analysis}

Statistical analyses were carried out using the general linear model procedure of the Statistical Analysis System (SAS) Release 9.01 package (2002). Means were compared using the Duncan's multiple range test at a level of significance of $p<0.05$ and the following model:

\section{Comparison of Duroc breeding stock lines}

$$
\begin{aligned}
& y_{i}=\mu+\tau_{i}+\varepsilon \\
& \text { where, } \\
& y=\text { observed value of the trait } \\
& \mu=\text { mean } \\
& \tau=\text { line effect (N farm, } \mathrm{W} \text { farm, } \mathrm{S} \text { farm, and } \mathrm{R} \text { farm) } \\
& \varepsilon=\text { random error }
\end{aligned}
$$

\section{Results and Discussion}

\section{Carcass characteristics of Duroc breeding stock lines in Korea}

The comparison of carcass characteristics in Duroc lines is explained in Table 2. Carcass weight was heavier in L4, whereas L2 was significantly lower $(p<0.05)$. In carcass length, L1 showed longer carcass length than the other lines $(p<0.05)$. The backfat thickness in Duroc lines was significantly higher in L3 than in the other lines, whereas L1 showed significantly thinner backfat thickness compared with that in the other lines $(p<0.05)$. Globally, Duroc pigs are used as a terminal sire to enhance carcass weight and intramuscular fat (Channon et al., 2004; Latorre et al., 2003; Ruusunen et al., 2012; Serrano et al., 2008; Suzuki et al., 2003). Most recently, Franco et al. (2014) reported that Celta crossed with Duroc lines had higher carcass yield as well as loin and ham percentage than pure Celta pigs (a Spanish native breed). Additionally, Bereskin et al. (1971) reported that the breed of the sire only significantly affected carcass length, but the breed of the dam significantly influenced all carcass traits including carcass length, backfat thickness, percentage of ham and loin, and loin-eye area. According to Soriano et al. (2005), comparison of carcass characteristics of progeny from Duroc sires in England, Spain, and Netherland revealed that Duroc progeny from the respective lines showed significant difference in carcass yield, carcass length, and backfat thickness $(p<0.05)$. Ramirez and Cava (2007) reported that progeny from different types of Duroc sires (DU1-high fattening type and DU2-meat production type) showed significant difference in carcass weight and backfat thickness $(p<0.05)$. DU1 progeny had higher carcass weight and backfat thickness compared with those of DU2 progeny. In this study, L3 and L4 had heavy carcass weights and thick backfat, whereas L1 and L2 had relatively light carcass weights and thin backfat. Moreover, Lonergan et al. (2001) reported that Duroc pigs that were selected for lean growth had significantly more lean gain, loin eye area, percentage lean, and less 10th-rib fat as well as backfat thickness.

\section{Meat quality characteristics of the longissimus muscle of Duroc breeding stock lines in Korea}

Meat quality characteristics of longissimus muscle from Duroc breeding stock lines are shown in Table 3. In chemical composition, L1 and L2 had significantly higher values in moisture and ash compared with L3 and L4. Alternatively, the protein contents of L1 and L2 were lower than those of L3 and L4 $(p<0.05)$. The highest fat content value among the longissimus muscle of Duroc breeding stock lines was observed in L3 $(p<0.05)$. In meat quality characteristics, $\mathrm{pH}_{24 \mathrm{~h}}$ values ranged from 5.65 to 5.79 , and L3 showed the lowest levels $(p<0.05)$. L4 showed a significantly higher WHC value than the other

Table 2. Carcass characteristics of Duroc breeding stock lines in Korea

\begin{tabular}{ccccc}
\hline \hline Items & $\mathrm{L} 1(\mathrm{n}=50)$ & $\mathrm{L} 2(\mathrm{n}=61)$ & $\mathrm{L} 3(\mathrm{n}=51)$ & $\mathrm{L} 4(\mathrm{n}=38)$ \\
\hline Carcass weight $(\mathrm{kg})$ & $85.88 \pm 9.42^{\mathrm{bc}}$ & $83.55 \pm 6.41^{\mathrm{c}}$ & $87.11 \pm 4.09^{\mathrm{b}}$ & $97.86 \pm 6.25^{\mathrm{a}}$ \\
Carcass length $(\mathrm{cm})$ & $85.31 \pm 3.29^{\mathrm{a}}$ & $77.82 \pm 2.69^{\mathrm{c}}$ & $79.51 \pm 5.41^{\mathrm{c}}$ & $82.04 \pm 2.75^{\mathrm{b}}$ \\
Backfat thickness $(\mathrm{mm})$ & $18.00 \pm 4.52^{\mathrm{d}}$ & $22.32 \pm 4.33^{\mathrm{c}}$ & $25.88 \pm 3.38^{\mathrm{a}}$ & $24.13 \pm 2.86^{\mathrm{b}}$ \\
\hline
\end{tabular}

${ }^{\mathrm{a}-\mathrm{d}}$ Means \pm SD with different superscription within the same row differ $(p<0.05)$. 
Table 3. Meat quality characteristics of the longissimus muscle of Duroc breeding stock lines in Korea

\begin{tabular}{|c|c|c|c|c|}
\hline Items & $\overline{\mathrm{L}} 1(\mathrm{n}=50)$ & L2 $(n=61)$ & $\overline{\mathrm{L}} 3(\mathrm{n}=51)$ & $\overline{\mathrm{L} 4(\mathrm{n}=38)}$ \\
\hline Moisture (\%) & $73.61 \pm 0.72^{\mathrm{a}}$ & $73.54 \pm 0.84^{\mathrm{a}}$ & $72.38 \pm 1.13^{b}$ & $72.66 \pm 0.99^{b}$ \\
\hline Protein $(\%)$ & $22.42 \pm 0.57^{b}$ & $22.52 \pm 0.70^{\mathrm{b}}$ & $23.16 \pm 0.76^{\mathrm{a}}$ & $23.24 \pm 0.76^{\mathrm{a}}$ \\
\hline Fat $(\%)$ & $2.78 \pm 0.62^{b}$ & $2.75 \pm 0.79^{b}$ & $3.41 \pm 1.19^{\mathrm{a}}$ & $3.06 \pm 1.10^{\mathrm{ab}}$ \\
\hline Ash (\%) & $1.17 \pm 0.21^{\mathrm{a}}$ & $1.18 \pm 0.39^{\mathrm{a}}$ & $1.04 \pm 0.19^{\mathrm{b}}$ & $0.94 \pm 0.15^{\mathrm{b}}$ \\
\hline $\mathrm{pH}_{24 \mathrm{~h}}$ & $5.75 \pm 0.14^{\mathrm{a}}$ & $5.74 \pm 0.13^{\mathrm{a}}$ & $5.65 \pm 0.09^{b}$ & $5.79 \pm 0.22^{\mathrm{a}}$ \\
\hline WHC (\%) & $56.83 \pm 3.38^{c}$ & $58.52 \pm 3.25^{\mathrm{b}}$ & $58.37 \pm 4.28^{\mathrm{bc}}$ & $61.66 \pm 4.59^{\mathrm{a}}$ \\
\hline Drip loss (\%) & $3.32 \pm 0.86^{\mathrm{b}}$ & $3.78 \pm 1.17^{\mathrm{b}}$ & $5.65 \pm 0.09^{\mathrm{a}}$ & $3.42 \pm 1.42^{\mathrm{b}}$ \\
\hline Cooking loss (\%) & $26.24 \pm 1.93^{\mathrm{c}}$ & $27.82 \pm 3.93^{\mathrm{b}}$ & $30.31 \pm 2.59^{\mathrm{a}}$ & $26.60 \pm 2.36^{\mathrm{c}}$ \\
\hline Shear force $(\mathrm{kg})$ & $1.28 \pm 0.21^{\mathrm{c}}$ & $1.40 \pm 0.22^{\mathrm{b}}$ & $1.63 \pm 0.32^{\mathrm{a}}$ & $1.72 \pm 0.37^{\mathrm{a}}$ \\
\hline \multirow{3}{*}{ Hunter color* } & $56.22 \pm 2.36^{\mathrm{a}}$ & $54.89 \pm 2.81^{b}$ & $56.65 \pm 2.45^{\mathrm{a}}$ & $55.53 \pm 3.18^{\mathrm{ab}}$ \\
\hline & $4.94 \pm 1.19^{\mathrm{ab}}$ & $4.64 \pm 1.04^{\mathrm{b}}$ & $4.68 \pm 0.83^{\mathrm{b}}$ & $5.28 \pm 0.74^{\mathrm{a}}$ \\
\hline & $7.99 \pm 0.70^{\mathrm{b}}$ & $8.26 \pm 0.95^{\mathrm{b}}$ & $8.04 \pm 1.04^{b}$ & $8.64 \pm 0.92^{\mathrm{a}}$ \\
\hline
\end{tabular}

*L (lightness), a (redness), b (yellowness)

${ }^{\mathrm{a}-\mathrm{c}}$ Means $\pm \mathrm{SD}$ with different superscripts within the same row $\operatorname{differ}(p<0.05)$.

lines, whereas L1 showed a lower WHC value compared with the other lines $(p<0.05)$. With regard to cooking and drip loss, L3 had significantly higher values compared with the other lines $(p<0.05)$. In shear force, L1 showed a significantly lower value compared with that of the other lines $(p<0.05)$. In Hunter color, significant difference was observed among the lines. Lightness value was lower in L2 than in the other lines $(p<0.05)$, whereas L4 showed significantly higher values of redness and yellowness compared with those of the other lines $(p<0.05)$. Ramirez and Cava (2007) assessed the meat quality of longissimus muscle using different types of Duroc sires that were consisted of a Duroc line with a higher level of fattening and a Duroc line with a higher percentage of meat cuts and low carcass fat. In the results, longissimus muscle of Duroc lines with higher percentages of meat cuts and low carcass fat showed the worst meat quality in postmortem $\mathrm{pH}$, cooking loss, drip loss, meat color, and showed the lowest percentages of intramuscular fat. Alternatively, Lonergan et al. (2001) reported that meat quality of longissimus muscle from Duroc pigs that were selected for lean growth were softer, more exudative, higher moisture content, higher shear force value, and less neutral lipid than control group. However, in that study, it was considered that L1 and L2 were of the lean growth type, which is not consistent with our report. In the study that was conducted by Cilla et al. (2006), three lines of Duroc showed significant difference in fat content of the main cuts including ham, loin, shoulder, belly, and tenderloin $(p<0.001)$. However, no significant difference was noted in meat quality parameters among Duroc lines.

\section{Sensory evaluation of the longissimus muscle of Duroc breeding stock lines in Korea}

Table 4 shows sensory evaluation of the longissimus muscle in Duroc breeding stock lines. Scores of attributes were expressed via a 5-point scale. Both tenderness and overall acceptability did not show significant differences. Alternatively, juiciness and flavor of L4 yielded higher scores compared with the other lines $(p<0.05)$. Cilla et al. (2006) reported that dry-cured hams from pigs that were crossed with three types of Duroc sire lines (DU1-high intramuscular fat type, DU2-intermediate type, and DU3lean and heavy type), and sensory analyses were conducted and acceptability was measured. As a result, drycured hams from DU1-sired pigs had higher overall acceptability. However, Ngapo et al. (2012a) determined that the degree of marbling did not influence the sensory scores of the pork neither roasted nor grilled, but the ageing method affected pork flavor and hardness. Lonergan et al. (2001) reported a comparison of meat quality between Duroc lines that were classified as either meat

Table 4. Sensory evaluation ${ }^{1)}$ of the longissimus muscle of Duroc breeding stock lines in Korea

\begin{tabular}{|c|c|c|c|c|}
\hline Items & L1 $(n=50)$ & $\bar{L} 2(n=61)$ & $\bar{L} 3(\mathrm{n}=51)$ & L4 $(n=38)$ \\
\hline Tenderness & $3.14 \pm 0.52$ & $3.12 \pm 0.41$ & $2.99 \pm 0.60$ & $3.17 \pm 0.69$ \\
\hline Juiciness & $3.04 \pm 0.38^{\mathrm{ab}}$ & $3.14 \pm 0.31^{\mathrm{ab}}$ & $2.99 \pm 0.47^{\mathrm{b}}$ & $3.19 \pm 0.55^{\mathrm{a}}$ \\
\hline Flavor & $3.03 \pm 0.32^{b}$ & $3.08 \pm 0.25^{\mathrm{ab}}$ & $3.08 \pm 0.43^{\mathrm{ab}}$ & $3.20 \pm 0.48^{\mathrm{a}}$ \\
\hline Overall acceptability & $3.10 \pm 0.38$ & $3.11 \pm 0.32$ & $3.02 \pm 0.45$ & $3.16 \pm 0.57$ \\
\hline
\end{tabular}

${ }^{\mathrm{a}, \mathrm{b}}$ Means $\pm \mathrm{SD}$ with different superscription within the same row differ $(p<0.05)$.

${ }^{1)} 1$ : very tough, dry, mild, and unacceptable, 5 : very tender, juicy, intense, and acceptable. 
production type or fat accumulation type. The line of the meat production type had significantly lower subjective firmness scores and was significantly more exudative. Moreover, shear force values were higher than those in the fat accumulation type. According to Steane (1986), it is generally accepted that an increased level of intramuscular fat has a positive influence on sensory qualities of pig meat and meat products.

\section{Conclusion}

Duroc pigs are commonly used as terminal sires in the commercial pig business. Therefore, we performed pork quality investigation of domestic Duroc breeding stock lines to help improve the development of pig breeding stock for the production of pork satisfied with consumers' needs. L1 and L2 possessed smaller carcass weights and thin backfat, whereas L3 and L4 had heavy carcass weights and thick backfat. The contents of fat and protein in L3 and L4 were higher than those in L1 and L2. With regard to meat quality characteristics, L1, L2, and L4 had higher $\mathrm{pHs}$ compared with L3. Additionally, L4 had a significantly higher WHC than the other lines. In sensory evaluation, L4 had the highest scores for both juiciness and flavor. Consequently, pork quality information from domestic Duroc breeding stock lines could be used to effectively improve pork quality.

\section{Acknowledgements}

This study was supported by research funding of Korea Animal Improvement Association. This research was also supported by Priority Research Centers Program through the National Research Foundation of Korea (NRF) funded by the Ministry of Education (2009-0093813).

\section{References}

1. AOAC (1995) Official methods of analysis. 13th Ed. Association of Official Analytical Chemists. Washington, D.C.

2. Bereskin, B., Shelby, C. E., and Hazel, L. N. (1971) Carcass traits of purebred Durocs and Yorkshires and their crosses. $J$. Anim. Sci. 32, 413-419.

3. Bertam, H. C., Straadt, I. K., Jensen, J. A., and Aaslyng, M. D. (2007) Relationship between water mobility and distribution and sensory attributes in pork slaughtered at an age between 90 and 180 days. Meat Sci. 77, 190-195.

4. Channon, H. A., Kerr, M. G., and Walker, P. J. (2004) Effect of Duroc content, sex and ageing period on meat and eating quality attributes of pork loin. Meat Sci. 66, 881-888.
5. Cilla, A., Altarriba, J., Guerrero, L., Gispert, M., Martinez, L., Moreno, C., Beltran, J. A., and Guardia, M. D., Diestre, A., Arnau, J., and Roncales, P. (2006) Effect of different Duroc line sires on carcass composition, meat quality and dry-cured ham acceptability. Meat Sci. 72, 252-260.

6. D'Souza, D. N., and Mullan, B. P. (2002) The effect of genotype, sex and management strategy on the eating quality of pork. Meat Sci. 60, 95-101.

7. Franco, D., Vazquez, J. A., and Lorenzo, J. M. (2014) Growth performance, carcass and meat quality of the Celta pig crossbred with Duroc and Landrance genotypes. Meat Sci. 96, 195-202.

8. Kang, S. J., Moon, Y. H., Park, K. S., Park, H. S., and Jeong, I. C. (2010) Effect of maturity and marbling score on meat quality properties in Korean native fattening Hanwoo. J. East Asian Soc. Dietary Life. 20, 248-253.

9. Kim, I. S., Jin, S. K., Song, Y. M., Park, K. H., Kang, S. M., Ha, J. H., Kim, I. J., Park, Y. S., and Kim, J. H. (2006) Quality characteristics of pork by sex on crossbred pigs. Korean J. Intl. Agri. 18, 34-39.

10. Kim, T. W., Kang, S. N., Jeong, J. Y., Kim, C. W., and Jin, S. K. (2011) Effects of feeding silage on pork quality by pig breeds. J. Agri. \& Life Sci. 45, 79-88.

11. Knap, P. W., van der Steen, H. A. M., and Plastow, G. S. (2001) Developments in pig breeding and the role of research. Livestock Prod. Sci. 72, 43-48.

12. Kolstad, K. and Vangen, O. (1996) Breed differences in maintenance requirements of growing pigs when accounting for changes in body composition. Livestock Prod. Sci. 47, 23-32.

13. Korea Animal Improvement Association. (2011) Pig improvement network program.

14. Korea Institute for Animal Product Quality Evaluation. (2001) Amendment of animal products grading service.

15. Laakkonen. E., Wellington, G. H., and Skerbon, J. W. (1970) Low temperature longtime heating of bovine. I. Changes in tenderness, water binding capacity, $\mathrm{pH}$ and amount of watersoluble component. J. Food. Sci. 35, 175-177.

16. Latorre, M. A., Lazaro, R., Valencia, D. G., Medel, P., and Mateos, G. G. (2003) The effects of gender and slaughter weight on the growth performance, carcass traits, and meat quality characteristics of heavy pigs. J. Anim. Sci. 82, 526-533.

17. Lonergan, S. M., Lonergan, E. H., Rowe, L. J., Kuhlers, D. L., and Jungst, S. B. (2001) Selection for lean growth efficiency in Duroc pigs influences pork quality. J. Anim. Sci. 79, 2075-2085.

18. Ministry of Agriculture, Food and Rural Affairs. (2014) Major statistics of agriculture, forestry, livestock food.

19. National Institute of Animal Science, RDA. (2007) Korean feeding standard for swine.

20. Ngapo, T. M., Riendeau, L., Laberge, C., and Fortin, J. (2012b) Marbling and ageing - Part 2. Consumer perception of sensory quality. Food Res. Int. 51, 985-991.

21. Ngapo, T. M., Riendeau, L., Laberge, C., and Fortin, J. (2012a) Marbling and ageing - Part I. Sensory quality of pork. Food Res. Int. 49, 396-405.

22. Park, C. S., Chung, S. B., Lee, K. S., and Park, Y. I. (1981) 
Comparison of reproductive performance for two-way and three-way crosses in swine. J. Ani. Sci. Tech. 23, 343-350.

23. Ramirez, R. and Cava, R. (2007) Carcass composition and meat quality of three different Iberian $\times$ Duroc genotype pigs. Meat Sci. 75, 388-396.

24. Ruusunen, M., Puolanne, E., Sevon-Aimonen, M. L., Partanen, K., Voutila, L., and Niemi, J. (2012) Carcass and meat quality traits of four different pig crosses. Meat Sci. 90, 543547.

25. SAS (2002) The SAS System Release 9.1, SAS Institute Inc., Cary, NC.

26. Serrano, M. P., Valencia, D. G., Nieto, M., Lazaro, R., and Mateos, G. G. (2008) Influence of sex and terminal sire line on performance and carcass and meat quality of Iberian pigs reared under intensive production systems. Meat Sci. 78, 420428.

27. Suzuki, K., Shibata, T., Kadowaki, H., Abe, H., and Toyoshima, T. (2003) Meat quality comparison of Berkshire, Duroc and crossbred pigs sired by Berkshire and Duroc.
Meat Sci. 64, 35-42.

28. Soriano, A., Quiles, R., Mariscal, C., and Ruiz, A, G. (2005) Pig sire type and sex affects on carcass traits, meat quality and physicochemical and sensory characteristics of Serrano dry-cured ham. J. Sci. Food. Agric. 85, 1914-1924.

29. Steane, D. E. (1986). The potential of the Duroc breed of pig. Res. Dev. Agric. 3, 153-157.

30. Tizioto, P. C., Meirelles, S. L., Veneroni, G. B., Tullio, R. R., Rosa, A. N., Alencar, M. M., Medeiros, S. R., Siqueira, F., Feijo, G. L., Silva, L. O., Jr. Torres, R. A., and Regitano, L. C. (2012) A SNP in ASAP1 gene is associated with meat quality and production traits in Nelore breed. Meat Sci. 92, 855857.

31. Wang, M. Q., Wang, C., Du, Y. J., Li, H., Tao, W. J., Ye, S. S., He, Y. D., and Chen, S. Y. (2014) Effects of chromium-loaded chitosan nanoparticles on growth, carcass characteristics, pork quality, and lipid metabolism in finishing pigs. Livestock Sci. 161, 123-129.

(Received 2014.10.23/Revised 2014.11.21/Accepted 2014.12.5) 